\title{
ON THE CHRONOLOGY OF THE RELIEFS WITH IMAGES OF CYBELE, HERMES AND HECATE FOUND IN THE NORTHERN BLACK SEA COAST
}

\begin{abstract}
The article is devoted to the reliefs with images of Cybele, Hermes and Hecate from Olbia and the Bosporus, which were recently dated to the first centuries AD. An early Hellenistic limestone relief bearing a similar scene discovered during excavations in Gorgippia (modern Anapa) in 2020, makes it possible to address once again the question of the origin of this subject, and the date of its appearance on the territory of the Black Sea Coast.
\end{abstract}

Keywords: Ancient Black Sea Coast, Olbia, the Bosporus, Gorgippia, reliefs with the images of Cybele, Hermes and Hecate

\section{PRZYCZYNEK DO CHRONOLOGII RELIEFÓW PRZESTAWIAJĄCYCH KYBELE, HERMESA I HEKATE, ZNALEZIONYCH NA PÓŁNOCNYM WYBRZEŻU MORZA CZARNEGO}

\begin{abstract}
ABSTRAKT Artykuł poświęcony jest reliefom z wizerunkami Kybele, Hermesa i Hekate z Olbii i Bosporu, datowanym na pierwsze wieki naszej ery. Wczesno hellenistyczny relief wapienny z podobną sceną, odkryty podczas wykopalisk w Gorgippii (współczesna Anapa) w 2020 roku, umożliwia podjęcie dyskusji na temat pochodzenia tego tematu i czasu jego pojawienia się na terytorium północnego wybrzeża Morza Czarnego.
\end{abstract}

Słowa kluczowe: Morze Czarne, Olbia, Bospor, Gorgippia, płaskorzeźby z wizerunkami Kybele, Hermesa i Hekate

The first finds of reliefs with a three-figure composition representing Cybele, Hermes and Hecate on the territory of the Northern Black Sea region date back to the beginning of the $20^{\text {th }}$ century. ${ }^{1}$ Specifically a limestone relief of this type (39x32x 17 $\mathrm{cm}$ ) was found by chance near Olbia ${ }^{2}$ in 1902. It was purchased immediately by Boris Farmakovskiy for Odessa Archaeological Museum (Fig. 1, 1). The relief is in the form of a naiskos, crowned with a triangular pediment, the slopes of which bend slightly. The figures of the deities occupy almost all the field of the relief field, both as regards width and height, following the principle of isocephaly. In the centre is Cybele, sitting on a throne with her feet on

1 The study was conducted for the state work № 0184-2019-0005. "Culture of Classical States of the Northern Black Sea Region. Subcultures of the ruling elite and ordinary population".

2 According to the words of peasants this find was discovered "in the area to the South of the village Parutino" (Farmakovskiy 1906, 293 a stool. She is usually referred to as the Mother of the Gods or the Phrygian Mother in the epigraphy of the Northern Black Sea Coast. ${ }^{3}$ Her head with a high kalathos is framed by wavy strands of hair. The goddess holds a phiale in her right hand and a tympanum in her. A lion cub is lying on her knees. To the left is Hermes dressed in a short chiton, with a petasos on his head, holding a caduceus and an oinochoe in his hands. On the other side of Cybele is Hecate, represented with two long torches raised in her hands. Like Hermes, she acts as a guide for the soul of the deceased wandering in their afterlife. It is possible that the choice of this subject has been made because of the initiation of the person making the dedication into the mysteries connected with the cult of Cybele which gave the hope of happiness after death. In this case the oinochoe held by Hermes acts as a symbol of ritual purification. ${ }^{4}$

3 Rusjaeva 2005, 154, 168; Bykovskaya 2020, 254-255.

4 Roller 1999, 202. 
In the same year 1902, the best relief with a similar three-figured subject was found in a grave on the northern slope of Mithridates' Mount in Kerch (Fig. 1, 2) and Vladislav Shkorpil bought it for the Kerch Museum. ${ }^{5}$ The height of the relief was $79 \mathrm{~cm}$, the width $51 \mathrm{~cm}$, and the thickness $17 \mathrm{~cm}$. In this case the pediment of the naiskos is decorated with acroteria, and its tympanum with a rosette. Small differences in details, such as the position of Hermes' right hand, the absence of a caduceus etc. allow us to speak about the desire to convey a compositional idea without following it exactly. ${ }^{6}$ The same can be said about other the Bosporan reliefs representing Cybele, Hermes and Hecate, but with more summary execution of the images, which may be due to the financial capabilities of the customers, or the different level of skill of the sculptors. The most indicative example is the naiskos discovered during the observation of building works in 1911 on Predtechenskaya Square in the centre of Kerch. Its pediment is practically cut off (Fig. 1, 3). The dimensions of the preserved part of the stele are 55 x $39 \times 13 \mathrm{~cm}$. The figures of the deities are executed in such low relief that Vladislav Shkorpil managed to identify only one of them correctly, which was the figure of Hermes depicted on the left with a petasos on his head and a winged caduceus in his hands. In the centre the figure of Cybele with her tympanum was described by Vladislav Shkorpil as a sitting "bearded god with a mirror (?) in his left hand and wearing a hat that could be a kalathos or a Phrygian cap". Hecate with her torch is referred to as simply a "female figure". Another naiskos with the three-figure composition was found accidentally in 1929 on the territory of the necropolis of Nymphaion (Fig. 1, 4). Its dimensions are somewhat smaller: height of 40-46 cm, width of 35-36 $\mathrm{cm}$ and thickness of $10 \mathrm{~cm}^{8}$

All the reliefs mentioned above were accidental finds, and were dated to mainly within the $1^{\text {st }}$ century $\mathrm{BC}-3^{\text {rd }}$ century $\mathrm{AD}$ on purely stylistically grounds. ${ }^{9}$ The votive relief with Cybele, Hermes and Hecate found during the excavations of Tiritaka in 1984 was also attributed to the $1^{\text {st }}$ century $\mathrm{AD},{ }^{10}$ although its surface is so weath-

5 Škorpil 1913, 200; Античная скульптура 2004, 64.

6 Yuliy Marti believed that this relief is "a quite vital and therefore can be attributed to the $1^{\text {st }}$ century BC." (Marti 1934, 65).

7 Shkorpil 1914, 21, rys. 6.

8 Antichnaya skul'ptura 2004, 65.

9 Kobylina $1978,35-37,49-50$, rys. 10-12, 40; Goroncharovskiy 1999, 226.

10 Antichnaya skul'ptura 2004, 66. ered and worn (Fig. 1, 5) that it clearly belongs to an earlier time. Its height is $50 \mathrm{~cm}$, width $41 \mathrm{~cm}$, and thickness $10 \mathrm{~cm}$. The relief is without a pediment, and has a ledge at the bottom for mounting it on a pedestal.

Meanwhile, writing on the subject of the Pantikapaion' naiskos found in 1902, Vladislav Shkorpil had noted that the closest analogy for it are two small marble reliefs of the $4^{\text {th }}$ century BC discovered by German archaeologists at the end of the $19^{\text {th }}$ century on the northern slope of the Acropolis of Athens. Only the lower part with width of $31 \mathrm{~cm}$ and height of $28 \mathrm{~cm}$ has been preserved from one of them, but all the individuals depicted are quite recognizable due to such attributes as tympanum, phiale, lion cub, oinochoe and torches (Fig. 2, 1). ${ }^{11}$ The other relief is a naiskos, where the Mother of the Gods has been depicted in the centre, and smaller figures of her companions have been placed at the base of the side pilasters. The main differences in interpretation of the scene are the lion sitting next to Cybele, and the figure of Pan with syrinx placed above Hecate (Fig. 2, 2). ${ }^{12}$ The votive relief from Piraeus with the same arrangement of figures was purchased for the Berlin Museum in 1879, and dates to the second half of the $4^{\text {th }}$ century BC (Fig. 2, 3). ${ }^{13}$ The relief, which demonstrates a completely original interpretation of the composition of the three divine characters, is also related to Piraeus (Fig. 2, 4). In this case the figure of seated Cybele with tympanum and a bowl is located on the left. Hecate with torch stands in front of the goddess. She followed by Hermes with an oinochoe in his outstretched hand. ${ }^{14}$ It is also worth noting the naiskos inscribed with a dedication of Crito to the Mother of the Gods, ${ }^{15}$ found in the western part of the Athenian Agora during work carried out on the Metroon. ${ }^{16}$ In this case the full-face figures of Hermes and Hecate are shown next to Cybele. Perhaps some sculptural group, which was popular in Athens during the Late Classical and Early Hellenistic period, served as the prototype for all the reliefs mentioned above. Outside of Attica this three-figure composition is practically unknown throughout the Mediterranean region. In such case the design could have been copied on the Northern Black Sea Coast thanks to

11 Schrader 1896, 278.

12 Schrader 1896, 279.

13 Conze 1891, 258.

14 Vermaseren 1977, pl. 23.

15 Champion-Smith 1998, 101, pl. 28.

16 Once there was a famous statue of the Mother of the Gods by Phidias or his pupil Agoracritos (Paus. I, 3, 5; Plin. NH, XXXVI, 17; Salis 1913, 1-26). 
the close trading and cultural connections it enjoyed with the "School of Hellas" during the $4^{\text {th }}$ and the beginning of the $3^{\text {rd }}$ centuries BC. In this regard it is interesting to note that all the Bosporan lapidary dedications to the Phrygian Mother date to the reign of king Perisades II (284-245 BC). ${ }^{17}$ One of them mentions the priestess Hestia, the daughter of Metrodoros. It speaks about the official nature of the cult of the goddess and the existence of her temple in Panticapaion. Votive offerings to Cybele, especially terracotta, are also most numerous for the $3^{\text {rd }}$ century BC. ${ }^{18}$ Thus, if we follow the traditional dating of the reliefs under consideration from Olbia and Panticapaion, there is a gap of several centuries between them and their Attic prototypes.

In this respect, the find made in 2020 by the expedition of "Kuban Archeology" during excavations on the western outskirts of ancient Gorgippia (modern Anapa) it is of considerable interest. It sheds some light on the date reliefs depicting Cybele, Hermes and Hecate appeared on the Northern Black Sea Coast. It is a limestone slab $(47 \times 43 \times 10 \mathrm{~cm})$ with a votive relief, which is quite close to the Pantikapaion' relief of 1902 in the manner of execution, and may even have been made in the same workshop. The dating of the Gorgippian relief is established by the fact that it was reused around the middle of the $3^{\text {rd }}$ century $\mathrm{BC}$ during the reconstruction of the building which had been destroyed by a powerful earthquake of 8-9 points. $^{19}$

The stele with the figures of Cybele, Hermes and Hecate (Fig. 3) is crowned with a triangular pediment decorated with acroteria. Under it there is a poorly preserved inscription APTEMI [- - ]. Most likely it is the beginning of the name of the dedicant. We can note that in Early Hellenistic Gorgippia, a theophoric name of such a form, Artemidoros, is attested only once. It appears as a patronymic in the well-known list of winners at sporting events, which dates to the first half of the $3^{\text {rd }}$ century $\mathrm{BC} .{ }^{20}$ Among the paleographic features the alpha with a straight transverse bar, and the $m u$ with inclined lateral lines are characteristic for Bosporan inscriptions in the Early Hellenistic period. ${ }^{21}$

Taking into account the archaeological context in which the Gorgippian naiskos was discovered, it becomes obvious that at least some of the votive reliefs with the images Cybele, Hermes and Hecate

17 Korpus bosporskih nadpisey 1965, n. 21, 23.

18 Glushets 2006, 101.

19 See: Korzhenkov et al. 2018, 117.

20 Korpus bosporskih nadpisey 1965, n. 1137.

21 Boltunova, Knipovich 1962, 13, tabl. III. from Black Sea Coast are older than previously thought, otherwise the chronological gap between them is difficult to explain.

\section{Literature}

Antichnaya skul ptura 2004. Lapidarnaya kollekciya. Iz sobraniya Kerchenskogo gosudarstvennogo istoriko-kul turnogo zapovednika. Kiev.

Boltunova A. I., Knipovich T. N. 1962. Ocherki istorii grecheskogo lapidarnogo pis 'ma na Bospore. „Numizmatika i epigrafika” III, 3-31.

Champion-Smith V.A. 1998. Pausanias in Athens: An Archaeological Commentary on the Agora of Athens. London.

Conze A. 1891. Beschreibung der antiken Skulpturen mit Aussxhluss der pergamenischen Fundstücke. Berlin.

Farmakovskiy B.V. 1906. Raskopki v Ol'vii v 19021903 godax."Izvestiya Arkheologicheskoy komissii", 13, 1-318.

Glushets L. N. 2006. Izobrazheniya bogini na trone $v$ kollekcii terrakot Kerchenskogo istoriko-kul turnogo zapovednika. „Nauchny”j sbornik Kerchenskogo zapovednika", 1, 99-121.

Goroncharovskiy V. A. 1999. K voprosu o kul 'te Kibely na Bospore. „STRATUM plus”, 3, 224227.

Kobylina M. M. 1978. Izobrazheniya vostochnych bozhestv $v$ Severnom Prichernomor'e v pervye veka n. e. Moskva.

Korzhenkov A. M., Lar'kov A. S., Ovsyuchenko A. N., Sokolova O. Yu. 2018. Sledy sil'nykh zemletryaseniy $\mathrm{v}$ ruinakh bosporskogo goroda Nimfeya. „Bosporskie issledovaniya”, XXXVII, 111-138.

Marti Yu.Yu. 1934. Novy 'e e pigraficheskie pamyatniki Bospora. „Izvestiya Gosudarstvennoy akademii istorii material'noy kultury", 104, 57-89.

Roller E.L. 1999. In search of God the Mother: The Cult of Anatolian Cybele. London.

Rusyaeva A. S. 2005. Religiya pontijskikh ellinov. Kiev.

Salis H. 1913. Die Göttermutter des Agorakritos. "Jahrbuch des Deutschen Archäologischen Instituts", 28, 1-26.

Schrader H. 1896. Die Ausgrabungen am Westabhange der Akropolis. "Athenische Mitteilungen des Deutschen Archäologischen Institut", 21, 265-286.

Shkorpil V. V. 1914. Otchet o raskopkax v g. Kerchi i na Tamanskom poluostrove $v 1911$ godu. "Izvestiya Arkheologicheskoy komissii", 56, 1-74. 
Škorpil V. 1913. Kybelin kult v řiši Bosporske. In: Sbornik praci filologických dvornimu radoví professoru Josefu Kralovi $k$ Šedesatým naroženínam. Praha, 190-203.

Vermaseren, M.J. 1977. Cybele and Attis. The Myth and the Cult. London.
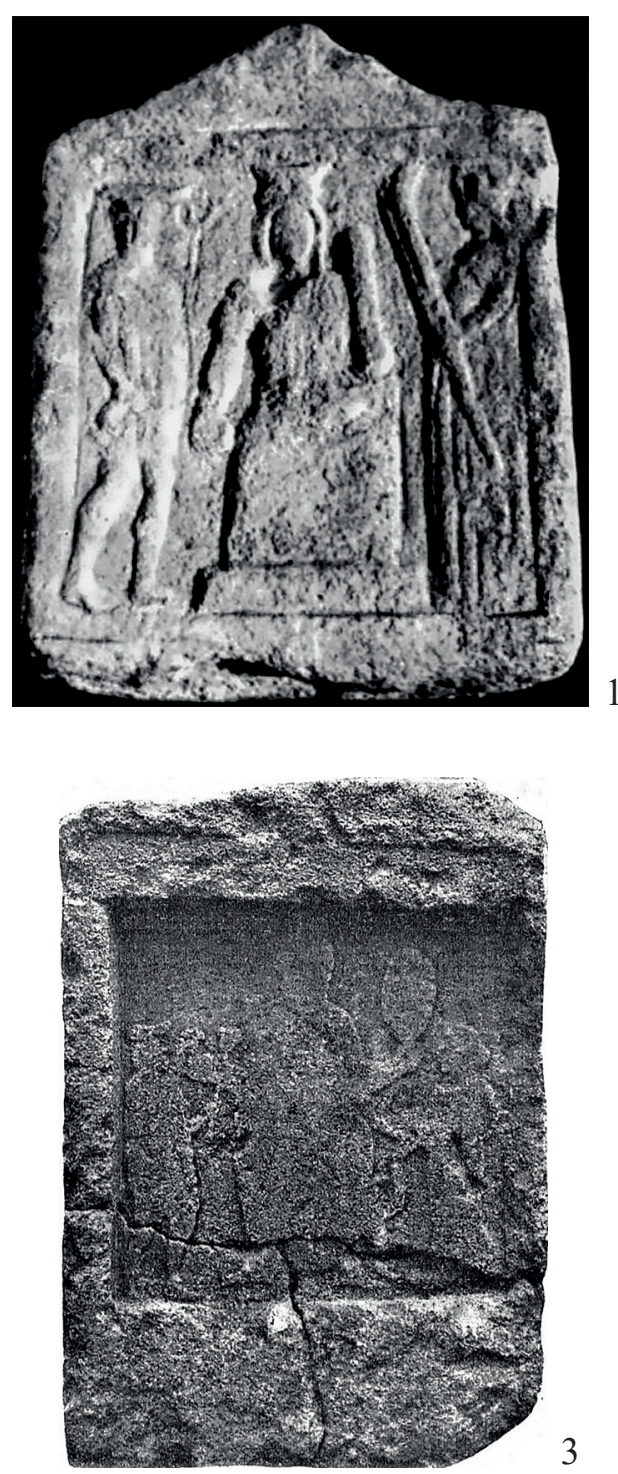

3

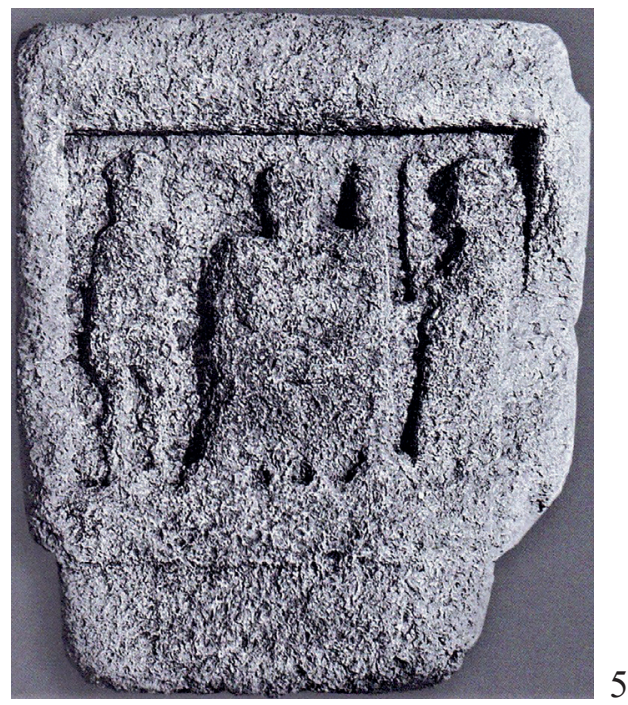

Vladimir Goroncharovskiy

ORCID 0000-0002-4405-716X

Institute for History of Material Culture RAS

goronvladimir@yandex.ru
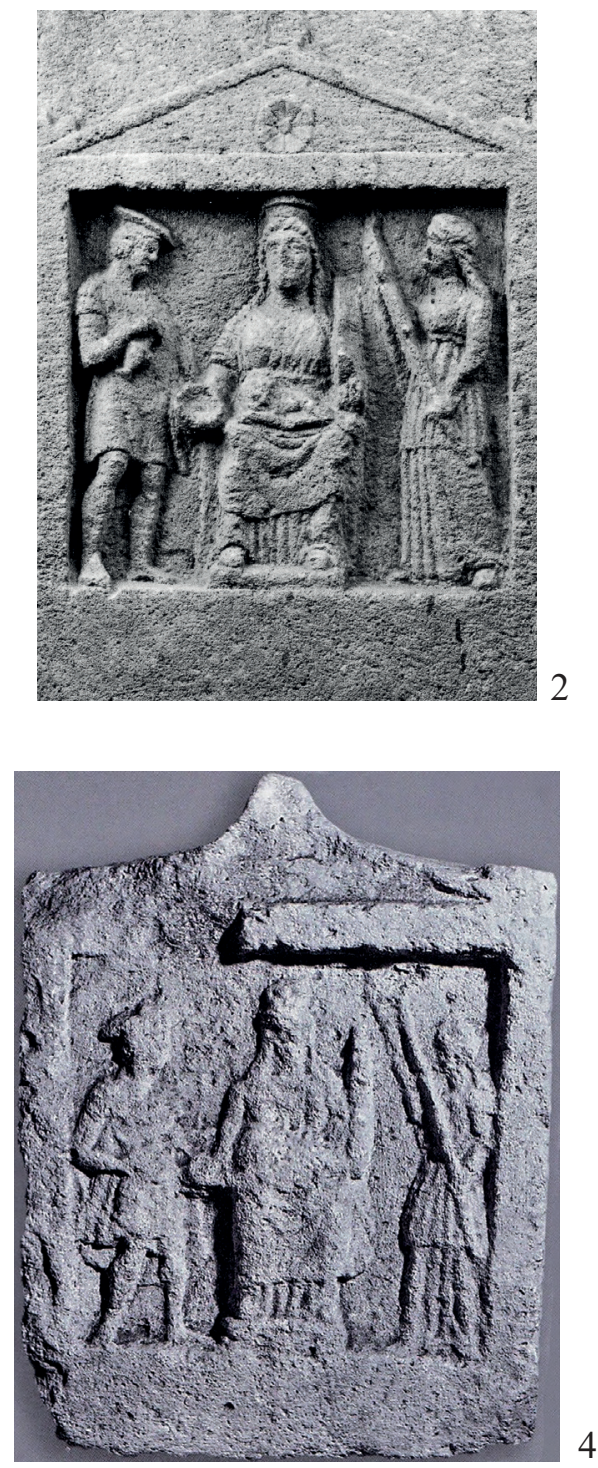

Fig. 1. Votive relief depicting Cybele, Hermes and Hekate found on the territory of the Northern Black Sea Coast:

1 - from Olbia (by Kobylina 1978, 67, rys. 11);

2, 3 - from Kertch (by Shkorpil 1914, 17, rys. 6; Marti 1934, 66, rys. 5);

4 - from the vicinity of the Nymphaion (by Marti 1934, 66, rys. 4);

5 - from Tyritake (by Antichnaya skul'ptura 2004, 66) 

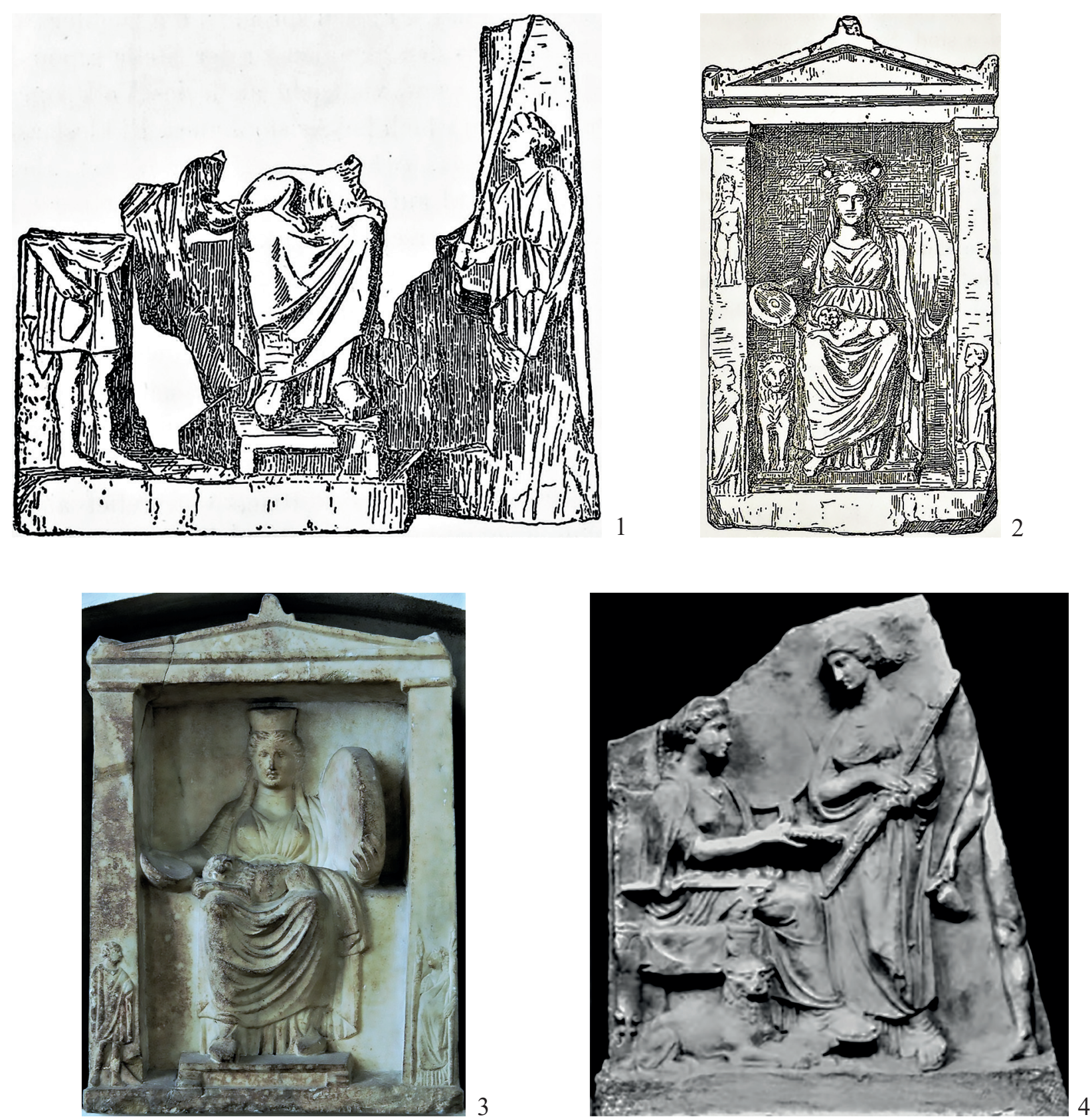

Fig. 2. Votive relief depicting Cybele, Hermes and Hekate from Attica:

1, 2 - from Athens (Schrader H. 1896, 278-279);

3, 4 - from Piraeus (Photo S. I. Sosnovskiy [CC BY-SA 4.0]) 


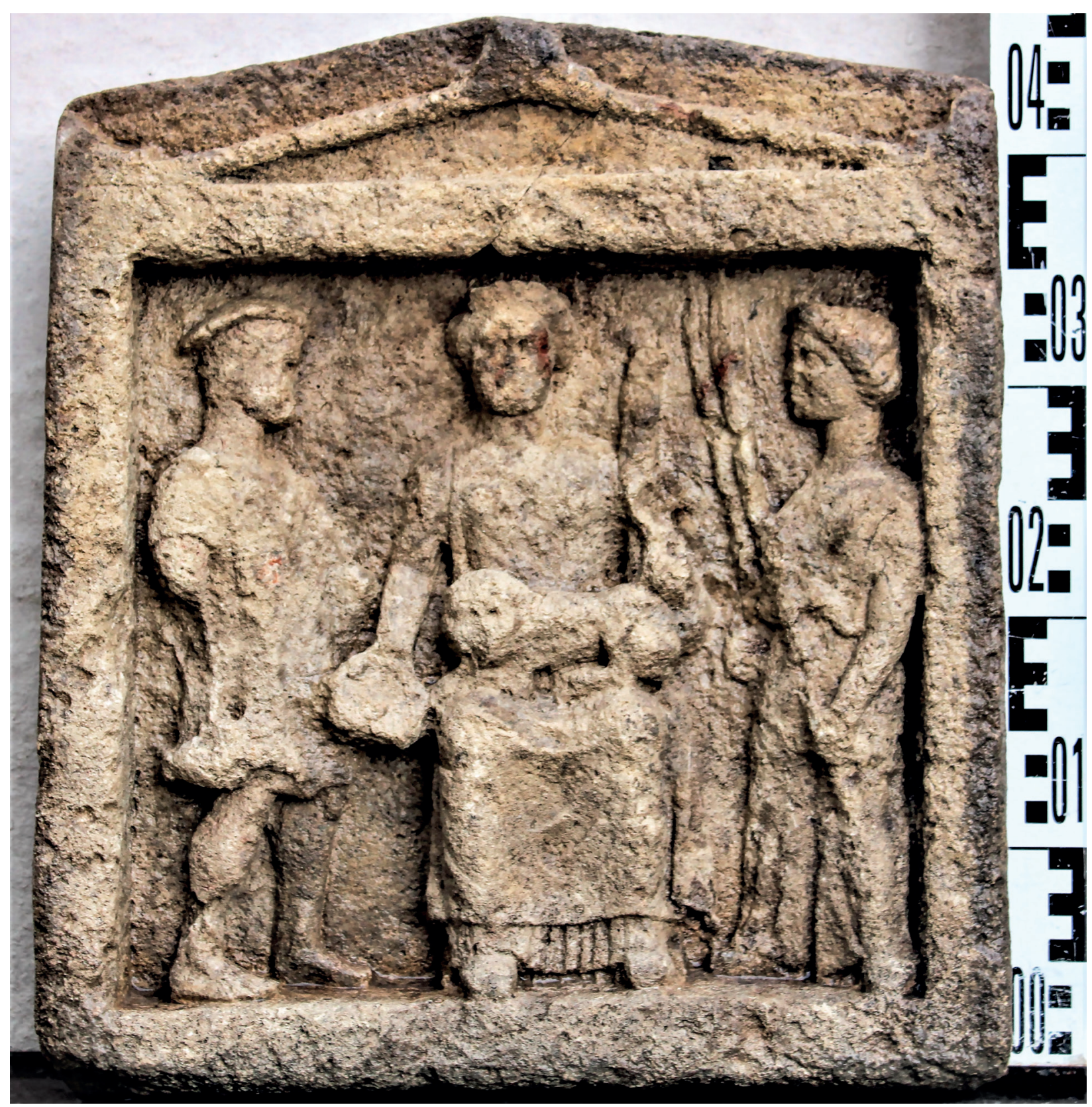

Fig. 3. Votive relief from Gorgippia (Photo of author) 